Картавцев Р.Л.

\title{
Експертне визначення механізмів державно-приватного партнерства по забезпеченню закладів охорони здоров'я медичним обладнанням
}

\author{
ДП «Політехмед», м. Київ, Україна \\ ptmref@ukr.net
}

\author{
Картавцев Р.Л. \\ Экспертное определение механизмов государственно- \\ частного партнерства по обеспечению учреждений \\ здравоохранения медицинским оборудованием \\ ГП «Политехмед», г. Киев, Украина
}

\author{
Kartavtsev R.L. \\ Expert definition of mechanisms \\ of public-private partnership to provide \\ healthcare institutions with medical equipment \\ PE "Polytehmed", Kyiv, Ukraine
}

\section{Вступ}

Питанню забезпечення закладів охорони здоров'я медичним обладнанням останнім часом присвячена низка наукових публікацій $[1,2]$.

В зарубіжних та вітчизняних наукових публікаціях [3-5] наводяться дані впливу забезпеченості закладів здоров'я високовартісним обладнанням на ефективність та результативність лікувального процесу, в тому числі на рівень летальності пацієнтів [6,7].

Питання забезпечення закладів охорони здоров'я медичним обладнанням особливої актуальності набуває на сучасному етапі реформування системи охорони здоров'я та впровадження державних гарантій медичної допомоги. На виконання Закону України „Про державні фінансові гарантії медичного обслуговування населення" [8] створена Національна служба здоров'я України [9] розроблені якою пакети медичних послуг та умови укладання договорів між закладами охорони здоров'я та Національною службою здоров'я [10] вимагають наявності в перших певного медичного обладнання яке необхідне для надання відповідної якісної медичної допомоги.

При цьому аналіз наукових публікацій вказує, що рівень забезпеченості закладів охорони здоров'я медичним обладнанням, особливо високовартісним, є недостатнім [11,12].

Вирішення даної проблеми може бути здійснено із застосуванням механізму державно-приватного партнерства, що визначено на законодавчому рівні [13] i чому сприяє проведена автономізація закладів охорони здоров'я [14].

Вказане i визначило актуальність даного дослідження.

Мета - визначити найбільш прийнятні механізми державно-приватного партнерства по забезпеченню закладів охорони здоров'я медичним обладнанням.

\section{Матеріали та методи}

При проведенні дослідження використано соціологічний та статистичний методи дослідження. За допомогою соціологічного методу було опитано 50 експертів - організаторів охорони здоров'я - керівників комунальних закладів охорони здоров'я (3О3) спеціалізованої та високоспеціалізованої медичної допомоги та 12 керівників приватних закладів охорони здоров'я.

\section{Результати дослідження та їх обговорення}

На початку дослідження було вивчено задоволеність експертів рівнем оснащення закладів охорони здоров'я медичним обладнанням та можливість укласти 3 Національною службою здоров'я України (НС3У) договорів на надання медичної допомоги, яку їх заклади охорони здоров'я надавали до настання даного етапу реформи охорони здоров'я. Отримані результати наведено в табл. 1 .

Керівники комунальних закладів охорони здоров'я в своїй більшості $\epsilon$ не задоволеними рівнем забезпеченості медичним обладнанням: діагностичним - 14,0\%, лікувальним - 32,0\%, реабілітаційним - 18,0\%. Існуючий рівень забезпеченості закладів охорони здоров'я медичним обладнанням дозволив тільки у $14,0 \%$ укласти 3 НСЗУ договори на надання всіх видів медичної допомоги які надавалася раніше.

Керівники приватних закладів охорони здоров'я показали вищій рівень задоволеності забезпеченням медичним обладнанням: діагностичним - 75,0\%, лікувальним - 83,3\%, реабілітаційним - 58,3\%. Раніше приватні заклади охорони здоров'я не надавали медичні послуги населенню за державний кошт. На момент дослідження 41,7\% приватних закладів охорони здоров'я укласти з НСЗУ договори на надання медичних послуг населенню за державний кошт. 
Далі було досліджено питання щодо можливих забезпеченню закладів охорони здоров'я медичним механізмів державно-приватного партнерства по обладнанням (табл. 2).

Таблиця 1. Задоволеність експертів рівнем забезпечення закладів охорони здоров'я медичним обладнанням та можливість укласти договори із НСЗУ

\begin{tabular}{|c|c|c|c|c|}
\hline \multirow[t]{2}{*}{ Показник } & \multicolumn{2}{|c|}{$\begin{array}{c}\text { Керівники } \\
\text { державного сектору }\end{array}$} & \multicolumn{2}{|c|}{$\begin{array}{c}\text { Керівники } \\
\text { приватного сектору }\end{array}$} \\
\hline & абс. & $\%$ & абос. & $\%$ \\
\hline $\begin{array}{l}\text { Задоволений рівнем забезпеченості діагностичним медичним } \\
\text { обладнанням }\end{array}$ & 7 & 14,0 & 9 & 75,0 \\
\hline $\begin{array}{l}\text { Задоволений рівнем забезпеченості лікувальним медичним } \\
\text { обладнанням }\end{array}$ & 16 & 32,0 & 10 & 83,3 \\
\hline $\begin{array}{l}\text { Задоволений рівнем забезпеченості реабілітаційним медичним } \\
\text { обладнанням }\end{array}$ & 9 & 18,0 & 7 & 58,3 \\
\hline $\begin{array}{l}\text { Рівень забезпеченості } 303 \text { медичним обладнанням дозволив } \\
\text { укласти з НСзУ договори на надання всіх видів медичної } \\
\text { допомоги які надавалася раніше }\end{array}$ & 7 & 14,0 & - & - \\
\hline $\begin{array}{l}\text { Рівень забезпеченості } 303 \text { медичним обладнанням не дозволив } \\
\text { укласти з НСЗУ договори на надання всіх видів медичної } \\
\text { допомоги які надавалася раніше }\end{array}$ & 43 & 86,0 & - & - \\
\hline
\end{tabular}

\section{Таблиця 2. Оцінка можливих механізмів державно-приватного партнерства} по забезпеченню закладів охорони здоров'я медичним обладнанням

\section{Показник}

Оренда приватним сектором приміщення в комунальному 303 для медичного обладнання з повною оплатою орендної плати та надання платних послуг пацієнтам $3 \mathrm{O} 3$

Цілодобова оренда комунальним 303 медичного обладнання у приватному секторі з повною оплатою орендної плати

Оренда приватним сектором приміщення в комунальному 303 для медичного обладнання та оплатою 303 отриманих пацієнтами цілодобово послуг за направленнями лікарів закладу Надання $3 \mathrm{O} 3$ приватному сектору приміщення для медичного обладнання без орендної плати та використанням в ургентних випадках обладнання безоплатно

Безоплатна (пільгова) оренда приватним сектором приміщення в комунальному 303 для медичного обладнання з наданням на ньому послуг пацієнтам безоплатно за узгодженим графіком Оплата комунальних послуг за оренду приватним сектором приміщення в комунальному 303 для медичного обладнання : при різних механізмах проводиться орендарем

Оплата комунальних послуг за оренду приватним сектором приміщення в комунальному 303 для медичного обладнання : при різних механізмах проводиться орендатором

Отримані результати вказують на те, що експерти підтримують рівні механізми державно-приватного партнерства по забезпеченню закладів охорони здоров'я медичним обладнанням, але найвищий рівень їх підтримки набула оренда приватним сектором приміщення в комунальному $3 \mathrm{O} 3$ для медичного обладнання та оплатою $3 \mathrm{O} 3$ отриманих пацієнтами

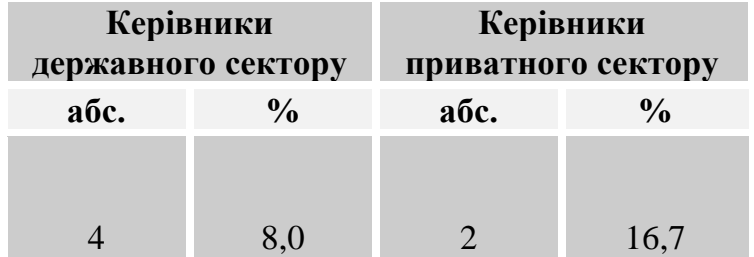

5

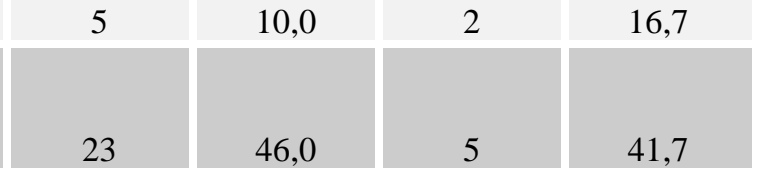

6

12,0

1

8,3

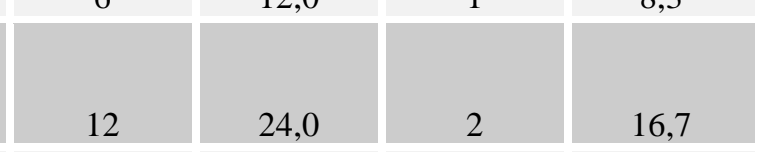

14,0

5

41,7

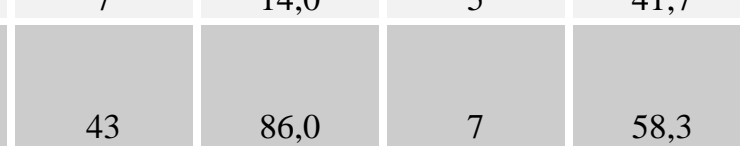




\section{Висновки}

Більшість експертів $(68,0 \%) \in$ незадоволеними рівнем забезпечення закладів охорони здоров'я медичним обладнанням. Вказане не дає змоги укладати договори 3 Національною службою здоров'я України на надання медичної допомоги за певними іiі видами. Експерти пропонують використовувати для забезпечення закладів охорони здоров'я різні механізми державно-приватного партнерства.

3 метою забезпечення закладів охорони здоров'я медичним обладнанням рекомендується використання різних механізмів державно-приватного партнерства в залежності від конкретної ситуації.

\section{Література}

1. Забезпеченість закладів охорони здоров'я високовартісним обладнанням. 2013 рік / В.В.Лазоришенець, Г.О.Слабкий, Р.Л.Картавцев, І.П.Семенів та інш. [монографія]. - К.: «МП Леся», 2014. - 192 с.

2. Результати інвентаризації високовартісного обладнання у комунальних закладах охорони здоров'я вторинного та третинного рівнів надання медичної допомоги в Україні / М.В. Шевченко, В.О. Лазаренко, Р.Л. Картавцев // Щорічна доповідь про стан здоров'я населення, санітарно-епідемічну ситуацію та результати діяльності системи охорони здоров’я України. 2013 рік / за ред. О. С. Мусія [монографія]. - К., 2014. - С. 259-270.

3. Князевич В. М. Характеристика забезпечення відділень інтенсивної терапії лікувальних закладів України моніторинговою апаратурою / В. М. Князевич // Современная педиатрия. - 2009. - № 1 (23). - С. 10-13.

4. Слабкий Г. О. Дилема раціоналізації ресурсів і запровадження нових технологій в анестезіології : наркозне обладнання та інгаляційна анестезія в Україні / Г. О. Слабкий, Р. М. Федосюк, О. М. Ковальова // Ліки України. 2009. - № 4 (130). - C. 122-127.

5. Картавцев Р.Л. Вплив забезпеченості медичним обладнанням на рівень летальності у відділеннях інтенсивної терапії / Г.О. Слабкий, Р.Л. Картавцев // Україна. Здоров’я нації. - 2014. - №4- С. 25-27.

6. Вплив основних складових лікувально-діагностичного процесу на летальність у відділеннях анестезіології та інтенсивної терапії / В. М. Князевич, Г. О. Слабкий, Р. М. Федосюк, О. М. Ковальова // Здоровье женщины. - 2009. № 6 (43). - C. 17-32.

7. Оснащеність лікарень швидкої медичної допомоги України базовим діагностичним та реанімаційним обладнанням / В. М. Князевич, Г. О. Слабкий, Р. М. Федосюк, О. М. Ковальова // Вісник проблем біології і медицини. 2009. - № 1. - С. 8-12.

8. Закон України „Про державні фінансові гарантії медичного обслуговування населення” 19 жовтня 2017 року № 2168-VIII [Електронний ресурс]. Режим доступу: http://search.ligazakon.ua/l_doc2.nsf/link1/T172168.html. - Haзва 3 екрану.

9. Про утворення національної служби здоров'я України : постанова Кабінету Міністрів України від 27.12.2017 № 1101. [Електронний ресурс]. Режим доступу: https://www.kmu.gov.ua/ua/npas/pro-utvorennya-nacionalnoyi-sluzhbizdorovya-ukrayini. - Назва з екрану.

10. Пакети медичних послуг. Зміст та підхід до контрактування закладів охорони здоров’я. Національна служба здоров'я України. Київ. 2020. - 59 с.

11. Картавцев Р.Л. Забезпеченість закладів охорони здоров'я вторинного рівня високовартісним обладнанням // Україна. Здоров’я нації. - 2014. - № 2 (30). - С. 62-65.

12. Качур О.Ю. Основні показники діяльності рентгенологічної служби системи охорони здоров'я України / О.Ю.Качур //Вісн. соц. гігієни та орг. охорони здоров’я України. - 2013. - № 4. - С. 9-12.

13. Закон України «Про державно-приватне партнерство» від 1 липня 2010 року № 2404-VI [Електронний peсурс]. Режим доступу: https://zakon.rada.gov.ua/laws/show/2404-17\#Text - Назва з екрану.

14. Закон України „Про внесення змін до деяких законодавчих актів України щодо удосконалення законодавства 3 питань діяльності закладів охорони здоров’я” від 06.04.2017 р. № 2002 [Електронний ресурс]. Режим доступу: http://www.ukrainepravo.com/law-making/bill_passed_by_legislature/zakon-ukraini-pro-vnesennya-zmindo-deyakikh-zakonodavchikh-aktiv-ukraini-shchodo-udoskonalennya-zak/- Назва з екрану.

\section{References}

1. Zabezpechenist zakladiv okhorony zdorovia vysokovartisnym obladnanniam. 2013 rik / V.V.Lazoryshenets, Slabkiy G.O., R.L.Kartavtsev, I.P.Semeniv ta insh. [monohrafiia]. - K.: «MP Lesia», 2014. - 192 s.

2. Rezultaty inventaryzatsii vysokovartisnoho obladnannia u komunalnykh zakladakh okhorony zdorovia vtorynnoho ta tretynnoho rivniv nadannia medychnoi dopomohy v Ukraini / M.V. Shevchenko, V.O. Lazarenko, R.L. Kartavtsev // Shchorichna dopovid pro stan zdorovia naselennia, sanitarno-epidemichnu sytuatsiiu ta rezultaty diialnosti systemy okhorony zdorovia Ukrainy. 2013 rik / za red. O. S. Musiia [monohrafiia]. - K., 2014. - S. $259-270$.

3. Kniazevych V. M. Kharakterystyka zabezpechennia viddilen intensyvnoi terapii likuvalnykh zakladiv Ukrainy monitorynhovoiu aparaturoiu / V. M. Kniazevych // Sovremennaia pedyatryia. - 2009. - № 1 (23). - S. 10-13. 
4. Slabkiy G.O. Dylema ratsionalizatsii resursiv i zaprovadzhennia novykh tekhnolohii v anesteziolohii : narkozne obladnannia ta inhaliatsiina anesteziia v Ukraini / G. O. Slabkiy, R. M. Fedosiuk, O. M. Kovalova // Liky Ukrainy. - 2009. № 4 (130). - S. 122-127.

5. Kartavtsev R.L. Vplyv zabezpechenosti medychnym obladnanniam na riven letalnosti u viddilenniakh intensyvnoi terapii / Slabkiy G.O., R.L. Kartavtsev // Ukraina. Zdorovia natsii. - 2014. - №4- S. 25-27.

6. Vplyv osnovnykh skladovykh likuvalno-diahnostychnoho protsesu na letalnist u viddilenniakh anesteziolohii ta intensyvnoi terapii / V. M. Kniazevych, Slabkiy G.O., R. M. Fedosiuk, O. M. Kovalova // Zdorove zhenshchyny. - 2009. № 6 (43). - S. 17-32.

7. Osnashchenist likaren shvydkoi medychnoi dopomohy Ukrainy bazovym diahnostychnym ta reanimatsiinym obladnanniam / V. M. Kniazevych, Slabkiy G.O., R. M. Fedosiuk, O. M. Kovalova // Visnyk problem biolohii i medytsyny. 2009. - № 1. - S. 8-12.

8. Zakon Ukrainy „Pro derzhavni finansovi harantii medychnoho obsluhovuvannia naselennia” 19 zhovtnia 2017 roku № 2168-VIII. [Elektronnyi resurs]. Rezhym dostupu: http://search.ligazakon.ua/l_doc2.nsf/link1/T172168.html Nazva z ekranu.

9. Pro utvorennia natsionalnoi sluzhby zdorovia Ukrainy : postanova Kabinetu Ministriv Ukrainy vid 27.12.2017 № 1101. [Elektronnyi resurs]. Rezhym dostupu: https://www.kmu.gov.ua/ua/npas/pro-utvorennya-nacionalnoyi-sluzhbizdorovya-ukrayini. - Nazva z ekranu.

10. Pakety medychnykh posluh. Zmist ta pidkhid do kontraktuvannia zakladiv okhorony zdorovia. Natsionalna sluzhba zdorovia Ukrainy. Kyiv. 2020. - 59 s.

11. Kartavtsev R.L. Zabezpechenist zakladiv okhorony zdorovia vtorynnoho rivnia vysokovartisnym obladnanniam // Ukraina. Zdorovia natsii. - 2014. - №2 (30). - S. 62- 65.

12. Kachur O.Iu. Osnovni pokaznyky diialnosti renthenolohichnoi sluzhby systemy okhorony zdorovia Ukrainy / O.Iu.Kachur // Visn. sots. hihiieny ta orh. okhorony zdorovia Ukrainy, 2013. - №4. - S. 9-12

13. Zakon Ukrainy «Pro derzhavno-pryvatne partnerstvo» vid 1 lypnia 2010 roku № 2404-VI [Elektronnyi resurs]. Rezhym dostupu: https://zakon.rada.gov.ua/laws/show/2404-17\#Text. - Nazva z ekranu.

14. Zakon Ukrainy „Pro vnesennia zmin do deiakykh zakonodavchykh aktiv Ukrainy shchodo udoskonalennia zakonodavstva z pytan diialnosti zakladiv okhorony zdorovia” vid 06.04.2017 r. № 2002 [Elektronnyi resurs]. Rezhym dostupu: http://www.ukrainepravo.com/law-making/bill_passed_by_legislature/zakon-ukraini-pro-vnesennya-zmin-dodeyakikh-zakonodavchikh-aktiv-ukraini-shchodo-udoskonalennya-zak/- Nazva z ekranu.

Дата надходження рукопису до редакції: 07.08.2020 p.

Мета роботи: визначити найбільш прийнятні механізми державно-приватного партнерства по забезпеченню закладів охорони здоров'я медичним обладнанням.

Матеріали та методи. При проведенні дослідження використано соціологічний та статистичний методи дослідження. За допомогою соціологічного методу було опитано 50 керівників комунальних закладів охорони здоров'я та 12 керівників приватних закладів охорони здоров'я.

Результати. Більшість експертів $(68,0 \%) є$ незадоволеними рівнем забезпечення закладів охорони здоров'я медичним обладнанням. Вказане не дає змоги укладати договори з Національною службою здоров’я України на надання медичної допомоги за певними її видами. Експерти пропонують використовувати для забезпечення закладів охорони здоров'я різні механізми державно- приватного партнерства.

Висновки. 3 метою забезпечення закладів охорони здоров'я медичним обладнанням рекомендується використання різних механізмів державно-приватного партнерства в залежності від конкретної ситуації.

Ключові слова: заклади охорони здоров'я, медичне обладнання, забезпечення, державно-приватне партнерство, механізми.

Цель работы: определить наиболее приемлемые механизмы государственно-частного партнерства по обеспечению учреждений здравоохранения медицинским оборудованием.

Материалы и методы. При проведении исследования применены социологический и статистический методы исследования. При помощи социологического метода было опрошено 50 руководителей коммунальных учреждений здравоохранения и 12 руководителей частных учреждений здравоохранения.

Результаты. Большинство экспертов $(68,0 \%)$ неудовлетворены уровнем обеспечения учреждений здравоохранения медицинским оборудованием. Указанное не дает возможности заключать договоры с Национальной службой здоровья Украины об оказании медицинской помощи по определенным ее видам. Эксперты предлагают использовать для обеспечения учреждений здравоохранения разные механизмы государственно-частного партнерства.

Выводы. С целью обеспечения учреждений здравоохранения медицинским оборудованием рекомендуется использование разных механизмов государственно-частного партнерства в зависимости от конкретной ситуации. 
Ключевые слова: учреждений здравоохранения, медицинское оборудование, обеспечение, государственночастное партнерство, механизмы.

Goal of research: to determine the most appropriate mechanisms of public-private partnership to provide healthcare institutions with medical equipment.

Materials and methods. Sociological and statistical research methods were applied during the research. 50 managers of public health care institutions and 12 heads of private health care institutions were interviewed with the help of the sociological method.

Results. The majority of experts $(68.0 \%)$ are dissatisfied with the level of provision of healthcare institutions with medical equipment. This does not allow to conclude contracts with the National Health Service of Ukraine for the provision of medical care for its certain types. Experts propose to use various mechanisms of public-private partnership to provide healthcare facilities.

Conclusions. In order to provide healthcare facilities with medical equipment, it is recommended to use different mechanisms of public-private partnership depending on a particular situation.

Key words: health care institutions, medical equipment, provision, public-private partnership, mechanism.

\section{Відомості про автора}

Картавцев Ростислав Леонідович - к.мед.н., ДП «Політехмед», Генеральний директор; м. Київ, вул. Нагірна, 25-27, 04107, Україна.

ptmref@ukr.net. 